\title{
Tverrprofesjonell praksis utfordrer samarbeidet mellom helsefagstudenter
}

Bente Norbye

Jeg lærte av dem, sykepleier, fysioterapeut og lege, altså medisinerstudent, om hvordan de jobber, litt hvordan vi i lag kunne jobbe og lærte litt mer av det med tverrfaglig samarbeid og fikk oppleve mer hvordan det fungerte. Og så lærte jeg mer om meg selv, jeg ble tryggere på meg selv. Man fikk på en måte en arena for å bare ... ble egentlig bare kastet ut i det og ble på en måte ... Rollen min ble mye viktigere enn jeg noen ganger før har opplevd, altså min rolle som ergoterapistudent. Den virker mye viktigere nå enn den har vært når jeg har vært i praksis tidligere. Min kunnskap ble verdsatt og bidro til nye input om pasienten som for eksempel medisinerstudenten ikke hadde fanget opp.

Ergoterapistudent i tredje studieår etter tverrprofesjonell praksis

\section{Innledning}

Dette kapittelet vil synliggjøre studenters erfaringer fra tverrprofesjonell praksis i et aksjonsforskningsprosjekt gjennomført i perioden 2014-2016 (Norbye, 2016). Prosjektet hadde som overordnet mål å etablere nye tverrfaglige praksisformer i samarbeid mellom utvalgte helsetjenester og fire profesjonsutdanninger. Prosjektet ble gjennomført i 
regi av Forskningsgruppa for profesjonsutdanning ved Institutt for helse og omsorgsfag og var finansiert av Det helsevitenskapelige fakultet ved UiT Norges arktiske universitet med midler til en stipendiatstilling samt driftsmidler. Som prosjektleder etablerte jeg kontakt med kommunehelsetjenesten i kommunene Lenvik og Bardu. Lenvik er vertskommune for et områdegeriatrisk senter (OGT). Dette er en enhet for rehabilitering som har en tverrfaglig profil, og den er derfor planlagt som en god arena for tverrprofesjonell samarbeidslæring. Bardu kommune har integrerte tjenester, der avdelingene i pleie- og omsorgstjenesten har ansvar for både pasienter som bor hjemme og på institusjon. Som lærer ved en desentralisert utdanning i over 25 år har jeg veiledet sykepleierstudenter i kommunehelsetjenesten i Bardu kommune, og jeg anså denne som en egnet praksisarena da de har gode faglige ressurser og er villige til å forsøke nye former for studenters læring og praksis. Dermed ble disse to distriktskommunene arena for en ny type studentpraksis: en tverrprofesjonell praksis med studenter fra utdanningene medisin, sykepleie, ergoterapi og fysioterapi. Denne typen praksis var inspirert av Linköpings universitet i Sverige, som over flere tiår har hatt tverrprofesjonell studentpraksis ved en sykehusavdeling (Wilhelmsson et al., 2009).

Tverrprofesjonelt samarbeid i helsetjenestene er satt som et globalt mål (WHO, 2010) for å imøtekomme behovet for koordinerte tjenester for pasienter med langvarige og komplekse problemstillinger. St.meld. nr. 47 (2008-2009). Samhandlingsreformen svarer også på oppfordringen for koordinerte tjenester og er den største helsereformen i moderne tid. Når kommunene etter 2012 fikk ansvar for å ferdigbehandle pasienter og følge opp utredning og behandling initiert av spesialisthelsetjenesten, ble det viktig for prosjektet å ha TPS for studentene i kommunehelsetjenesten. Flere prosjekter er knyttet til spesialisthelsetjenesten, og på grunn av sin sentrale rolle som praksissted for flere helsefaglige studenter, er flere studenter tilknyttet hver avdeling eller post. Tverrfaglig rehabilitering og oppfølging av pasienter er et nytt ansvar som kommunene fikk etter reformen.

Den demografiske utviklingen i et velferdssamfunn som Norge er som i andre vestlige land: Vi lever lenger og med flere sammensatte sykdommer og tilstander, og dette krever nye måter å samhandle på (Frenk et al., 2010; Thistlethwait, 2012; Benner, 2010); behandling og oppfølging krever koordinerte tjenester over tid. Tradisjonelt har profesjonsutdanninger globalt hatt lite fokus på tverrprofesjonelt samarbeid, utenom det samarbeidet 
som naturlig har skjedd i helsefaglige praksisstudier, der studentene har tatt kontakt og hatt samarbeid med andre helseprofesjoner.

Med min bakgrunn fra desentralisert sykepleierutdanning og bosatt i en distriktskommune, erfarte jeg at helsetjenesten fikk ansvar for stadig sykere pasienter, og at det var et mye større behov for koordinerte tjenester lokalt. Prosjektet skulle gi studentene mulighet til å samarbeide på nye måter, et nært samarbeid med hverandre. Når studenter lærer sammen, får de mulighet å utvikle en felles oppmerksomhet og oppøve tillit og respekt til hverandre (Hinshelwood \& Skogstad, 2000), som er viktige kvaliteter for godt samarbeid.

\section{Tverrprofesjonell samarbeidslæring}

Tverrprofesjonell samarbeidslæring (TPS) er en læringsform der studenter fra ulike profesjonsutdanninger lærer sammen og får innsikt i andres kompetanse og dermed også bedre forståelse av sin egen. Rolleforstålse og evne til samhandling er sentrale mål, der studenten skal lære av, om og med hverandre for å bedre samarbeid og kvalitet i helsetjenesten (Barr et al., 2017). Kunnskap om egen kompetanse ligger i bunnen for å utvikle forståelse for hva andre profesjoner kan bidra med, i en samhandlingssituasjon knyttet til et pasientforløp. Like viktig er det at samarbeidet skal bidra til å bedre pasientbehandlingen, og at det er pasientene som settes i fokus for samhandlingen. Dette er i tråd med WHO (2010) sin anbefaling om å etablere nye utdanningsformer mer i takt med helsetjenestens og pasientens behov for koordinerte tjenester.

Tverrprofesjonelt samarbeid er viktig for brukere med sammensatte behov for helsetjenester og er av stor betydning der brukeren vil ha behov for tjenester over tid. Det er antatt at samarbeidslæring kan gi større læringsutbytte for studentene i reelle samhandlingssituasjoner i praksisstudiene, der de sammen med studenter fra andre studieprogram før arbeidet sammen, enn som klasseromsundervisning og teoretisk casearbeid (Reeves et al., 2010, 2017). Det var derfor viktig å legge til rette for at studentene skulle utvikle samarbeidskompetanse og erfare betydningen av tverrprofesjonell samhandling i løpet av studietiden. TPS i reelle arbeidssituasjoner har også, 
naturlig nok, vist seg som viktig og effektivt og av betydning for å lære tverrprofesjonell samhandling (Reeves et al., 2010). Anderson (2016) sier at TPS utfordrer utdanningene, da profesjonsutdanningene tradisjonelt har stor grad av silotenkning og ikke har tradisjon på å samarbeide med andre utdanninger. Kritikken om silotenkning er også tydelig i rapporten «The Lancet commission» (Frenk et al., 2010), som etterlyser samarbeid i de helsefaglige utdanningene.

\section{Tverrprofesjonell praksis - kontekst}

To uker ble øremerket for gjennomføring av tverrprofesjonell studentpraksis, hvor studentene ble organisert i grupper med én student fra hver av de fire utdanningene. Praksisen ble planlagt $\mathrm{i}$ en periode mot slutten av studentenes respektive utdanninger. Tre perioder med tverrprofesjonell praksis ble gjennomført i løpet av 2014 og 2015, der studentene i stor grad skulle planlegge og utføre arbeidet med pasientene selvstendig, men i samarbeid med praksisstedet. Totalt gjennomførte 32 studenter fordelt på ni grupper sin tverrprofesjonelle praksisperiode på to uker. Studentene hadde en kontaktperson av egen helseprofesjon og en dedikert veileder som skulle veilede gruppen i samarbeidet. Helsetjenestene selv utpekte en veileder for hver av praksisplassene. Veilederne fikk tilbud om et langsgående kurs i tverrprofesjonell veiledning, som dels startet før praksisperioden, i tillegg til samlinger underveis. Veilederne skulle veilede studentgruppen om samarbeidet og ikke relatert til fagspesifikke problemstillinger. Hver studentgruppe skulle samarbeide om utvalgte pasienter med sammensatte og langvarige problemstillinger.

Prosjektet hadde som mål å prøve ut tverrprofesjonell praksis for studenter fra fire sentrale profesjonsutdanninger, for å utforske læringspotensialet av tverrprofesjonell praksis. Samarbeidet foregikk på ulike plan, på tvers av profesjonsutdanninger og på tvers av institutt. Læringen utfordret også nye samarbeidsformer i den kommunale tjenesten, da studentene til vanlig har sin praksis isolert fra andre profesjoners arbeid; medisinerstudenten er på legekontoret, fysioterapistudenten er sammen med andre i en fysioterapienhet, ergoterapistudenten er sammen med ergoterapeuten som besøker sine pasienter, og sykepleierstudenten er på sykehjemmet eller i hjemmebaserte tjenester sammen med sykepleierne der. Samhandlingsreformen utfordrer 
den kommunale tjenesten ved å gi den et mye større ansvar og rolle i pasientbehandlingen, og studentene deltok dermed i å prøve ut nye former for samarbeid og til hvordan koordinerte tjenester kunne bli til.

Samtidig var det viktig for prosjektet å etablere samarbeidet med kommunene der studentene gis mulighet for å samarbeide om reelle pasientforløp. Samarbeidet med helsetjenesten i å utvikle nye tverrfaglige praksisarenaer ville gi viktig prosesskunnskap om hvordan vi som ansatte ved de helsefaglige profesjonsutdanningene ved UiT kunne etablere fremtidige og nye praksisarenaer som møter behovet for koordinerte og sammensatte helsetjenester. For at studentene skal lære å samarbeide over profesjonsgrenser, er det anbefalt med godt planlagte sekvenser for samarbeid i praksisstudier, med minst en praksisutplassering, gjerne i kommunetjeneste eller i dedikerte studentposter (Brewer \& Stewart-Wynne, 2013; Jacobsen, 2016; Thomas \& Reeves, 2015). Det er i slike læringssituasjoner studentene får mulighet til å reflektere over samarbeid og får erfare effekten av slikt samarbeid.

\section{Aksjonsforskning}

Aksjonsforskningen i dette prosjektet er brukt som en tilnærming og en diskurs i utviklings- og endringsarbeidet, som er demokratisk rettet, der flere aktører samarbeider og deltar i en felles medvirkning og kritikk (Carr, 2007; Hiim, 2010; McNiff \& Whitehead, 2011). Prosjektets design var syklisk og i fire faser, se kort prosjektbeskrivelse ${ }^{1}$ og Norbye (2016). Hver fase bestod av forberedelser i praksisfeltet og i utdanning, gjennomføring av praksis og en felles workshop der behov for justeringer og endringer ble diskutert. Endringsarbeidet ble implementert og justert i samarbeid mellom veiledere, praksisfeltet, lærere og studenter, som en transformativ og refleksiv gjentagende prosess (reflective action) som beskrevet av McNiff \& Whitehead (2011) og Elliott (2001). Denne prosessen førte til en felles forstålse og ny kunnskap om implementering av TPS. Endringer og justeringer ble implementert, og små justeringer måtte inn etter hver prosjektfase. Prosjektet har generert ny kunnskap på bakgrunn av etnografisk design med observasjonsdata og dialog i feltarbeid, slik Gudmundsen et al. (2018, 2019,

Se kort prosjektark for prosjektet Tverrprofesjonell samarbeidslæring i helsefaglig praksis: https:/uit.no/ prosjekter/prosjekt?p_document_id=349592 
2020) beskriver. Feltarbeidet danner i denne konteksten grunnlaget for teoriutvikling knyttet til praksisteori (Nicolini et al., 2012; Wenger, 1998) og som aksjonsforskning der endret pasientbehandling ble resultatet av studentpraksis (Norbye, 2016). Fasene i prosjektet ble brukt som visualisering av prosjektets ulike deler, der egne workshops reflekterte behovet for praktiske justeringer og refleksivitet med innspill til teoridannelse om kunnskap rundt hvordan studentene lærer av, med og om hverandre. ${ }^{2}$ Slike refleksive workshops ble gjort i samarbeid med veilederne fra praksisfeltet, lærerne ved de involverte utdanningene ved UiT Norges arktiske universitet og med praksisfeltets deltakere, i prosjektets ulike faser. Studentene bidro som deltakere i prosjektet i perioder på to uker når praksis var dedikert for TPS, og gav konstruktive innspill til nødvendige endringer. For å få innsikt i studentens læring ble studentene intervjuet etter praksisperioden. Til intervjuet var det utviklet en egen intervjuguide som tok utgangspunkt i studentenes opplevelser som deltakere i tverrprofesjonell praksis.

Prosjektet ble søkt godkjent av personverntjenestene ved Norsk senter for forskningsdata i 2013. Prosjektbeskrivelsen, informert samtykke og intervjuguiden fikk godkjenning med prosjektnummer 34895.

Aksjonsforskningsprosjektet hadde som et overordnet mål å forbedre profesjonsutdanningene knyttet til tverrprofesjonelt samarbeid og få prosesskunnskap knyttet til hvordan nye praksisarenaer ville kunne utvikles. I dette kapittelet er det prosesskunnskap basert på kvalitative data om studentenes egne erfaringer som deltakere i tverrprofesjonell studentpraksis som blir fokusert, analysert og diskutert. I helsetjenesten ble det satt i gang prosesser for å forberede en felles studentpraksis i samarbeid med utdanningene. Praksisfeltet kjenner best til sine medarbeidere, pasientgrupper og sin arbeidsplass, og vil være de beste til å legge til rette for sine studenter i TPS-praksis. Dette praksisfellesskapet (Lave \& Wenger, 1991), som er unikt for avdelingen selv og deres arbeidsplass, måtte tilpasses og utvikles for tverrprofesjonell praksis, og det ble justert underveis i prosjektets ulike faser som tilsvarte hver praksisperiode. Hver fase (studentpraksis) ble etterfulgt av workshops med veilederne fra helsetjenestene samt lærerne. Justeringer og endringer ble gjennomført for å bedre studentenes praksis.

Definisjonen av tverrprofesjonell samarbeidslæring (TPS) er når to eller flere profesjoner lærer av, med og om hverandre for å bedre samarbeid og bedret pasientbehandling (CAIPE, 2002). 
Vi ønsker med intervjudataene å få innsikt i studentens egne opplevelser av å prøve ut en tverrprofesjonell praksis, som en ny læringsform for studentene og for praksisfeltet.

Studentene ble rekruttert av representantene for hver utdanning i prosjektgruppen for frivillig deltakelse i prosjektet. Studentene signerte samtykkeskjema og fikk informasjon om at de når som helst kunne trekke seg fra prosjektet. 32 studenter deltok i tverrprofesjonell praksis i løpet av disse to studieårene, fordelt på ni tverrprofesjonelle studentgrupper i de to kommunene. Studentene var alle på slutten av sin utdanning; medisinerstudentenes femte studieår, og for sykepleie, fysioterapi og ergoterapistudentenes tredje og siste studieår. Praksisperioden skulle inngå som en del av ordinære praksisstudier, men ble organisert slik at studentene kunne være sammen alle dagene i de to utpekte ukene.

For å få best mulig informasjon om studentenes læring ble alle studentene intervjuet før tverrprofesjonell praksis om deres tidligere erfaring fra samarbeid med andre profesjoner. Etter praksis ble studentene igjen intervjuet, noen i gruppe og noen individuelt. I tillegg ble en studentgruppe bedt om å tegne ned eventuelle endringer de selv erfarte i form av sirkler, der en sirkel representerte egen og andres samarbeidsområder, etter gjennomført praksis.

Prosjektgruppen utviklet i fellesskap en intervjuguide for et semistrukturert intervju. Det ble gjennomført syv gruppeintervju og ni individuelle intervju etter studentenes TPS-praksis. Intensjonen var å ha alle intervjuene som fokusgruppeintervju for å få frem studentenes felles refleksjoner, men i etterkant av TPS-praksis var studentene spredt på nye praksissteder i landsdelen, og det ble da gjennomført ni individuelle intervju. Intervjuenes form som enten individuelle intervju eller gruppeintervju ble da et pragmatisk valg for å få med stemmene til alle de deltagende studentene.

\section{Analyse}

Intervjuene ble ordrett transkribert og analysert med en kvalitativ innholdsanalyse (Malterud, 2012; Kvale \& Brinkmann, 2010) for å få frem mening i den transkriberte teksten på tvers av intervjuene. Den kvalitative innholdsanalysen egner seg for å få frem erfaringer og refleksjoner fra studentene og ville få frem nyanser på tvers av intervjuene, som kan føre til 
gjenkjennelse og forståelse ut fra studentenes perspektiv, slik de opplevde sin praksis. I henhold til Malteruds (2012) kvalitative innholdsanalyse ble følgende trinn fulgt:

1. Intervjuene ble gjennomlest flere ganger for å danne et helhetsinntrykk.

2. Dataene ble organisert etter intervjuguidens spørsmål.

3. Etter ny gjennomlesning ble meningsfulle utsagn og sitater trukket ut av datamaterialet som meningsenheter.

4. Meningsfortetting ble utført gjennom reduksjon og fortetting av teksten uten fortolkninger.

5. Tematikker ble identifisert, og innholdet blir her presentert som aktuelle tema.

Datamaterialet fra de forskjellige intervjuene ble ikke analysert opp mot hverandre, men ga til sammen et rikt materiale. Temaene som fremkom under analyseprosessen, var: 1. Det fagspesifikke kontra samarbeid. Studentene ble utfordret på hvordan de skulle arbeide sammen, å gjøre det fagspesifikke eller å starte samarbeidet, og på hvilken måte skulle dette gjøres. 2. Om å oppdage. Studentene oppdaget at de hadde nytte av å jobbe sammen, de oppdaget hva de andre kunne bidra med, og de oppdaget sin egen rolle i samarbeidet. 3. $\AA$ se sammenhenger via andre profesjoner. Pasientene ble presentert via andre profesjoner i samarbeidet. Dette var nytt for studentene og de så nye aspekter de ikke kunne ha oppdaget selv. 4. Om egen kontra andres roller. Studentene prøvde ut hvordan de kunne samarbeide med hverandre, to og to og sammen i felles diskusjoner. 5. Om det tverrfaglige. Studentene samarbeidet om ulike deler av sin praksis, de møttes for å diskutere hvordan de kunne kartlegge pasientens situasjon, de planla hvem som skulle arbeide sammen, og hvordan de kunne dokumentere arbeidet.

\section{Resultat og diskusjon}

Funnene fra analysen av intervjuene blir her presentert tematisk for så å avslutte med en overgripende diskusjon om TPS, som utfordrer tradisjoner og arbeidsformer i ulike profesjoner. 


\section{Det fagspesifikke arbeidet kontra samarbeidet med medstudentene}

Studentene som var i siste del av sin utdanning, bærer med seg erfaringer om hvordan samarbeidet mellom profesjonene har vært, om dette tidligere har vært et fokus, eller ikke. Nå var utgangspunktet at de skulle finne sine egne måter å samarbeide på, uten at det var definert av andre. Forutsetningene for samarbeid var ikke predefinert, og dette var nye samarbeidsformer.

Vi jobbet mye mer i lag og mye tettere på, spesielt de kartleggingsfasene enn det jeg hadde tenkt. Jeg så for meg sånn som jeg er vant til at «okei, nå har du en time hvor du går inn, og så har legen en time hvor den går inn» og så litt mer stykkevis og delt og så møtes vi etterpå og samsnakker det vi har funnet ut. Det var litt vanskelig, opplevde jeg, det var litt vanskelig å finne sin egen rolle i det. Å forsvare sitt eget fagområde, ble nesten litt for mye i lag.

Fysioterapistudent, 2014

Forventningene om å lære noe om sitt eget fag er fortsatt til stede når studentene er i tverrprofesjonell praksis. Fokuset endres underveis fra hva studenten kan lære om sin profesjon, til hva kan denne kunne bidra med av egen kunnskap. Ansvaret for sin egen profesjon er viktig for studenten, og hun føler ansvaret for å bringe frem sin fagspesifikke kunnskap til de andre.

Jeg vil si at utbyttemessig så har jeg ikke hatt den fagteknisk-spesifikke utviklingen. Men jeg er blitt veldig mye mer selvstendig kjenner jeg på selv. Jeg tok litt mer rollen «ja her er det faktisk jeg som er fysioterapeuten. Da skal jeg fremme mitt.» Hvis det skal være noe fysioterapi der så er det faktisk jeg som er nødt til å si det få det frem. Så det var litt godt å se at jeg faktisk kan ta den rollen nå.

Fysioterapistudent, 2014

Studentene har som forventning at de skal lære noe nytt, noe fagspesifikt, men sier samtidig at det å bli trygg og selvstendig er viktig: Det å kunne artikulere egen kunnskap er viktig både for å bli trygg på det selv og for å kunne forklare andre der kunnskapen er nyttig for å forstå sammenhenger som ikke er klart for studenter utenfor egen gruppe. 
Flere studenter uttrykker dette da alle de tidligere praksisstudiene har handlet om å lære noe nytt:

Utbyttet i forhold til medisin var ganske lite. Utbyttet i forhold til det å lære kanskje mer å samarbeide og lære mer om andre og ikke minst hva andre profesjoner arbeider med, det var veldig bra. Men hvis erfaringen blir å komme til nytte, og det tror jeg det blir, så var det veldig gunstig. Å skjønne mer hva andre driver med og hvordan de tenker.

Medisinerstudent, 2014

Studentene har en forventning om å lære fagspesifikk kunnskap i sine praksisstudier og opplever at denne forventningen ikke blir innfridd. De er selvsagt fokusert på hva de skal lære om sitt eget fagområde, og opplever at de må få med seg mest mulig i løpet av praksisstudiene. Tverrprofesjonell praksis utfordret spesielt medisinerstudentene, som i sin praksis i allmennmedisin ville ha hatt mange flere egne pasientkonsultasjoner på et legekontor. Det ligger en bekymring for om praksistiden blir brukt hensiktsmessig, selv om samarbeidet med medstudentene oppleves lærerikt.

\section{Om å oppdage}

Studentene i en tverrprofesjonell studentgruppe utfører egne profesjonsrelaterte oppgaver hos pasienten alene, i stedet for å gå inn til pasienten sammen. For å bruke tiden de har sammen konstruktivt, så forteller de hverandre hva de har gjort, hva de observerer og hvordan de vurderer det fra sitt ståsted, og hva de selv vektlegger ut fra sin profesjon. Medisinerstudenten sier de løste det nesten som en case - de bruker den pedagogiske læreformen de kjenner fra utdanningene, som en bro til den praksissituasjonen de er delaktige i, men som de ikke har vært i. De hjelper hverandre inn i situasjonen ved å beskrive og fortelle for å få et felles utgangspunkt for å inkludere de andre studentene. Studentene tar for gitt at det de selv observerer, er relevant for de andre.

Og vi hadde alle veldig mye tid, så vi hadde tid til å sette oss ned å snakke. Siden sykepleieren og fysioterapeuten var innom alle de pasientene som jeg var innom på intermediærenheten, så for at vi skulle 
få mest mulig ut av det så diskuterte vi pasientene som om at vi alle skulle ha vært med. Sånn at hvis fysioterapeuten hadde vært inne, hva ville hun gjort? Jeg fortalte hva som var problemstillingen - det ble nesten som et case-arbeid. Vi diskuterte alle pasientene selv om ikke alle var innom. Og da kunne de komme med «ja har du sett på hvordan de gjør det og det?» og da tenkte jeg «hvorfor skal jeg gjøre det». Hvorfor skal jeg tenke på hvordan de reiser seg ut av sengen. Bare at vi kom med veldig mange synspunkter som gjorde at vi fikk øynene opp for hverandre.

Medisinerstudent, 2015

Medisinerstudenten får videre hjelp av medstudentene til å se hele pasientforløpet og det pasienten trengte før hun kunne reise hjem. De to studentene utfyller hverandres faglige ståsted, fra det spesifikke som skjer her og nå, til hvordan skal pasienten skal klare seg hjemme. Ved å delta i det praktiske arbeidet to og to sammen oppdaget de hva som måtte gjøres før pasienten dro hjem.

Vi hadde veldig mange kolspasienter eller hjertesyke pasienter. Det var kjempebra å faktisk få se alt hva de kan og hvordan muligheter man har. Der er det fokus på at pasientene skal fort hjem og klare seg hjemme, ikke sant. Å bli bedre slik at de slipper å bli innlagt flere ganger. Så det er litt mer fokus på hva som kommer videre. Så der er det jo kjempeviktig med fysioterapeuten og legge til rette for at det faktisk skal gå bedre med dem. Ikke bare proppe i dem masse medisiner og håpe på det beste. Så ja, vi lærte veldig mye av hverandre.

Medisinerstudent, 2015

Sykepleierstudenten bruker sin kunnskap om ernæring og viser de andre medstudentene hvordan dette blir gjort. Hun bruker sin faglige kunnskap intuitivt da dette er sykepleierens område. Hun viser frem sitt eget og viser medstudentene hvordan dette gjøres, og hun sier:

«Pasienten fikk ikke i seg nok mat. De andre visste ikke at sykepleierne kunne så mye om ernæring, og måten vi screener og registrerer og foreslår tiltak ... det var nytt for dem da, både det faglige innholdet, men også at det var noe vi kunne.» Sykepleierstudent, 2014.

Studentene prøver ut måter å samarbeide på. Teamarbeidet oppstår når studentene får vist frem egen kunnskap, og hvordan de sammen kan utvikle 
ny kunnskap og erfaring. Slik kan studentene få respons fra medstudenter, og det styrker egen kunnskap og samholdet mellom studentene i et team (Barr \& Brewer, 2016.)

\section{A se sammenhenger via andre profesjoner}

Studentene vil ta i bruk de verktøyene de har til rådighet, ved kartleggingen av pasientens situasjon. Når pasienten har sammensatte problemområder, så er utfordringene større. Det som umiddelbart ser greit ut ved hjelp av en test, er det nødvendigvis ikke.

Jeg lærte masse, og jeg føler det er noe jeg kan ta med meg videre og. Ikke bare tenke på at nå skal vi få laboratoriesvarene til å være grønne, men vi skal faktisk ha et menneske som funker. Det var veldig interessant. Og noe som også er veldig viktig å se på. For det er noe som kan være veldig vanskelig å finne på et laboratorieark. Det å skjønne hvordan ting funker. Du må egentlig se det!

Medisinerstudent, 2014

Medisinerstudenten oppdager sammenhenger hun vanligvis ikke får ta del i. Hun kan det medisinske og er vant til å bruke ulike verktøy for å analysere, men når kart og terreng ikke passer - det at analyseverktøyene kan brukes, men har begrensing i forhold til det kompliserte bildet, ser hun tydelig i samarbeidet med de andre studentene. Det er i det komplekse at studentene virkelig får brukt hverandres kompetanse og dermed kan se nye sammenhenger. Studenten fortsetter;

Slik som med pasienten som gikk skjevt, og hadde en blanding av alkoholisk demens og slag. Og han var under opptrening. En MMS var ganske bra. Jeg gjorde en klokketest som var helt normal. Så satte ergoterapistudenten i gang ADL-trening på kjøkkenet og stue, og da fungerte han ikke noe bra. Hadde det her vært på et sykehus så hadde jeg jo sendt han hjem og «ja det her går bra», eller på legekontoret. Men dette fungerte ikke. Og det var jo helt åpenbart at det var noe som ikke var på plass.

Medisinerstudent, 2014 
De konkrete handlingene som utføres er viktig for medstudentene fordi det hjelper dem i å forstå hva de andre profesjonene gjør, og hvilken kunnskap de tar i bruk. I avdelingene henvises ofte pasientene til ergoterapi eller fysioterapi uten at de vanligvis ikke vet hva ergoterapeuten eller fysioterapeuten kan fange opp. Det blir utenfor deres felt og område. Heller ikke hvordan dette kan følges opp av pasienten selv, og hvordan oppfølging kan følges opp av avdelingen.

Og så er det sånn med fysio- og ergo, - man sier at pasienten har behov for fysio- eller skal få besøk av ergoterapeuten i en time. Så får de det og så går man ut, da er ikke sykepleierne der fordi man har andre oppgaver. Det å kunne se hva som foregår fordi ofte er det sykepleierne som følger det opp. Vi får en bedre forståelse av både hvor viktig det er å følge opp fra dag til dag, og at det ikke egentlig er så vanskelig. Altså, når du har fått et treningsopplegg så krever det jo egentlig ganske lite! Den viktigste jobben er jo gjort i det å identifisere utfordringene og finne øvelser og tiltak. Og det gjør og kan fysioterapeuten og ergoterapeuten gjøre, og da er det enklere for oss å følge det opp. Det har vært veldig fint å få en bedre forståelse av liksom både hva de fokuserer på, men også helt konkrete øvelser og trening.

Sykepleierstudent, 2014

Studentene får hjelp av medstudentene til å forstå pasientens problemer på nye og forskjellige måter. En kartlegging gir ikke hele bildet, men må utfylles av undersøkelser som gir nyanser. Slik kan studentenes profesjonskunnskap overlappe og utfylle hverandre. Men for å kunne utfylle hverandre må de vite om hverandres områder, vite om den andres kunnskap og hva den andre kan finne ut av og tilrettelegge for. Slik er målet for TPS at studentene skal kunne lære om, med og av hverandre for å kunne tilrettelegge for et fremtidig samarbeid om pasienter med sammensatte og langvarige utfordringer (WHO, 2010). Mange av disse pasientene opplever fragmentert hjelp, der de selv må være koordinator mellom ulike hjelpeinstanser. 


\section{Om egen og andres roller}

Studentene fikk ingen retningslinjer eller anbefalinger om hvordan de skulle etablere samarbeid, dette skulle de finne ut sammen. Det kunne ta tid, og det var enkelte ganger problematisk å finne en samarbeidsform som fungerte for alle i teamet.

En sykepleierstudent forteller at hun tidlig i praksisperioden var opptatt med å gjøre de sykepleiefaglige oppgavene først: Hun hjalp to pleietrengende pasienter med sitt morgenstell for å komme opp og få frokost, før hun kunne møte de andre studentene. Medisinerstudenten gikk også til sine oppgaver, og det ble vanskelig å koordinere samarbeidet. Studentene går til det kjente, og veilederen møtte ikke studentenes behov for samordning tidlig i praksisperioden. Studentene prøvde å gripe det kjente og det forventede, samtidig som de skulle samarbeide med andre. Der ingen av studentene selv tok initiativ til å lede samtalen om samarbeid, fikk de ingen avklaring på hvordan de kunne utforske samarbeidet. I en avdeling der rollene var tradisjonelle og der legene og fysioterapeutene ble kontaktet gjennom konsultasjon, for å ta egne fagspesifikke oppgaver, ble det vanskelig for studentene å forme det tverrprofesjonelle arbeidet selv. Rolleforventningene fra praksisstedet kunne også ha påvirket studentene. En annen gruppe studenter fortalte at medisinerstudenten kom innom innimellom, og ikke deltok i planleggingen. Det ligger ulike forventninger til samarbeidet når enkeltstudenter først går til sitt eget, før samarbeidet kan begynne. Samarbeidet kan ses på som noe ekstra og ikke like presserende som de profesjonsspesifikke oppgavene. Medisinerstudentene fremhever spesielt at samarbeidet og samtalene om pasientene studentene imellom tar lang tid. Forventningen om at praksisstudier er som forberedelse til arbeidslivet ligger implisitt. Det å finne nye måter å arbeide på kunne føre til frustrasjon med hensyn til hva egen rolle da ble. En medisinerstudent uttrykker dette slik:

Det var litt vanskelig å finne sin rolle. Fordi både i sykehuspraksis og allmennpraksisen så hadde jeg jo vært vant til at pasientene kommer til meg med et problem som jeg skal løse, mens her så hadde vi jo to pasienter. Vi jobbet totalt med tre pasienter disse to ukene, to som var i omsorgsbolig og ei som var på sykehjemmet. Og da måtte vi begynne helt på scratch og begynne med «hva kan vi ta tak i her» $\mathrm{i}$ stedet for at vi får et sånn konkret problem som vi skal løse eller. Så 
sånn sett syntes jeg det var vanskelig. Det tok veldig lang tid å finne hva man kunne gjøre. Så det var kanskje det som var mest utfordrende synes jeg.

Medisinerstudent, 2015

Slik kunne forventningene om samarbeid sprike for de ulike studentene og utfordre samarbeidet. Lite samsvar mellom tidligere praksiser og hverdagslivet som ventet etter endt utdanning, gjør at det for enkeltstudenter oppleves som uvant og lite realistisk å samarbeide slik. Ulike forventninger kunne utfordre samarbeidet, selv om dette ikke nødvendigvis ble sagt, men erfart.

Men det ble kanskje ulike oppfatninger av hva et samarbeid var. Kanskje legestudenten oppfattet det mer som at jeg gjør mitt og så gjør du ditt og så gjør sykepleieren sitt og så møtes vi og så snakker vi om det. Sånn utover så var det jo jeg og sykepleierstudenten som hadde det beste samarbeidet sånn som vi anså det da med tanke på det som skjedde i begynnelsen da. Men man kanskje la litt ... altså en feil oppfatning av hva et samarbeid var, at det ikke var bare de samtalene man hadde i lag som var, men at man skulle ha vært litt mer alle sammen i lag på ulike ting.

Ergoterapistudent, 2014

Studentene forsøkte å få til samarbeidet, men det kunne være vanskelig å finne en form som passet alle. Kanskje var dette ikke diskutert studentene imellom, men det sies ikke. Ergoterapistudenten fikk et godt samarbeid med sykepleierstudenten, men syntes det var vanskelig å få til samme samarbeid med medisinerstudenten. Medisinerstudenten gjorde imidlertid egne fagspesifikke oppgaver først, for så å rydde plass til en felles diskusjon. Konflikt rundt prioritering og lite avklarte gjøremål kan danne grunnlag for å klargjøre hvordan de kan samarbeide, noe denne studentgruppen ikke klarte å få til. Veiledning vil i slike situasjoner kunne bidra til at ulikhetene blir til muligheter, ved å være sensitive for hverandre og rollene de har i samarbeidet (Freeman, Wright \& Lindquist, 2010). Forutsetningen for at et tverrprofesjonelt samarbeid skal kunne bli etablert og godt for alle som deltar, er at en avklarer samarbeidet på forhånd. Studentene fikk i oppgave å gjøre dette selv, men uten at noen tok initiativ til å avklare samarbeidsformen som skulle være til pasientens beste, kunne det fort bli fragmentert og uklart. 


\section{Om det tverrfaglige - å utfylle faglig kunnskap i samarbeidet}

Å være på slutten av sin profesjonsutdanning betyr at de fleste studentene har et grep om sin rolle og sin profesjonsspesifikke kunnskap. Men å vite hvordan de kan utfylle hverandre, er lite tematisert, noe som studentene oppdager i denne tverrprofesjonelle praksisperioden. En ergoterapistudent uttrykker det slik:

Jeg føler meg trygg i rollen og jeg vet min oppgave, men det jeg opplevde var egentlig at vi var veldig mye mer lik enn jeg i utgangspunktet hadde trodd. Jeg så til og med at legen hadde mer av dette i sin utdannelse, av dette med å se hele mennesket. Sykepleier og fysioterapeut var også lik i en del ting. Sykepleieren i forhold til dette med hvordan ha en dag, fra morgen til kveld, i forhold til hvordan du gjennomfører aktiviteter, og fysioterapeuten i forhold til hvordan du gjør aktivitetene. Så det overrasket meg veldig mye, og vi fikk mange gode diskusjoner på det. For selv om vi var like, så var vi litt ulike. Sammen hjalp vi hverandre.

Ergoterapistudent, 2014

Studentene arbeider vanligvis tett sammen med sine veiledere $\mathrm{i}$ egen profesjon. Nå må de henvende seg til medstudentene fra andre profesjoner med sine refleksjoner. Ved å lufte dette høyt, som studenten sier, blir det faglige sagt høyt og holdt frem i gruppa.

Men i forhold til det tverrfaglige. Vi er jo vant med å ha våre, for eksempel hvis jeg er på sykehuset så er jeg vant med å ha overlegen eller assistentlegen veldig nært da så jeg kan spørre med en gang. Det hadde jeg jo ikke der, og det hadde heller ikke fysioterapistudenten eller noen av de andre. Så vi syntes det var veldig godt å ha hverandre bare for å kunne tenke høyt da om de vurderingene vi har gjort for å ha noen som har hørt og kanskje kan være enige. Eller bare for å ha lufta det ut, bli litt mer sikker på deg selv. Så flere av de andre studentene sa at de følte at vi var en trygghet sammen, bare få diskutert det og få sagt det høyt og bare få tenkt litt selv da. Det var veldig fint.

Medisinerstudent, 2014 
Refleksjonen som skjer når en deler tanker med andre, gir også en stor mulighet for læring. Den faglige refleksjonen skjedde her i en kontekst av et felles studentmøte, der studentene deler erfaringer og utveksler meninger med medstudentene. Studentene er aktive og deltakende og kommer med innspill til hverandre. Læring er slik en dimensjon av sosial praksis (Lave \& Wenger, 1991), et viktig redskap for læring. Om det gjelder et fagspesifikt spørsmål, så skjer refleksjonen i dialog med medstudentene, og studenten hører sin egen argumentasjon når hun forklarer sine faglige begrunnelser for de andre. Slik en fysioterapistudent også sa når hun forklarte og begrunnet handlingsalternativene for de andre studentene, hun hørte sin egen argumentasjon og forstod bedre sin faglige begrunnelse. Uten respons fra de andre, men med dem som tilhørere, så forstod hun sitt eget fagspesifikke dilemma og klargjorde for seg selv hva hun måtte gjøre. Studenten sa at hos en annen fysioterapeut ville vedkommende fătt vite svaret, men nå forstod vedkommende det selv. Refleksjonen og begrunnelsen som skjer når studentene setter ord på det som vanligvis er fagspesifikke spørsmål, ordlegges slik at andre forstår det, slik språket er viktig for en felles forståelse av fagene og det profesjonsspesifikke. En slik oversettelse av fagtekniske begrep til andre helseprofesjoner bidrar også til studentens egen forståelse. Refleksjonen gjør noe med de faglige begrunnelsene som er implisitt når fagpersoner diskuterer med hverandre, men som eksplisitt må sies til de andre som ikke er i fagområdet. Her får studentene mulighet til å tenke selv, gjennom fokusert refleksjon som kritisk vurderer sin egen praksis.

\section{TPS utfordrer tradisjoner og arbeidsformer}

Å legge til rette for gode læringsituasjoner i en tverrfaglig praksis vil være å utfordre eksisterende praksisformer, noe studentene uttrykker som både utfordrende og lærerikt. De savner eksplisitt å lære det profesjonsspesifikke, samtidig som de erkjenner at de lærer om andres roller og kompetanser, og lærer noen ganger også av hverandre. Gode læringsmiljø støtter små grupper som samarbeider tett sammen, og med en veileder, der de får mulighet til å bli oppmerksom på egen, så vel som andres verdier og normer (Freeman, Wright $\&$ Lindqvist, 2010). Det reelle samarbeidet, der studenter arbeider sammen om pasienter med komplekse problemstillinger, er de beste læresituasjonene, 
ifølge en studie av Derbyshire (2017). I vår studie gir også studentene uttrykk for at de lærte av hverandre. De ble de utfordret på sitt fag, som representant for sitt fag, samtidig som de måtte ta inn andres aspekter. Samtidig ser vi her at studentenes forventning til hverandre ikke helt er samsvarende. De prøver seg frem med ulike former for samarbeid.

Samarbeidet blir tydelig utfordret når studenter forsøker å både gjøre som tidligere praksiser, som sykepleierstudenten som først utfører avansert sykepleie om morgenen til to pasienter, før hun kan initiere samarbeidet med de andre. Det samme med medisinerstudenten som ventet på at medstudentene var ferdige, for så å være klar til et møte. Arbeidsoppgavene de gjør forut for samarbeidet blir da sett på, bevisst eller ubevisst, som arbeid som ikke angår de andre, og som går forut for samarbeidet, altså det profesjonsspesifikke arbeidet.

Studentene hadde 14 dager dedikert til å samarbeide om pasienter valgt ut av praksisplassen, og en utfordring var at samarbeidet skulle utformes av de selv som gruppe. I en studentgruppe ble ikke samarbeidet sett på som likeverdig arbeid, og samarbeidsformen er ikke godt nok diskutert. Der forventningene ikke ble avklart, gikk studentene heller til kjente oppgaver og ventet med samarbeidet. Her kunne en veileder ha hjulpet studentene til eksplisitt å uttale og avklare forventninger, og legge planer for tidspunkt for å møtes og planlegge samarbeidet. Veilederne ble også oppmerksomme på dette og initierte til at studentene avklarte forventninger, og hvordan de kunne samarbeide. Derbyshire (2017) finner at studentene lærer best samarbeid der det allerede er kultur for samarbeid på arbeidsplassen. Studentgruppene var fordelt på ulike avdelinger, en av avdelingene var tverrfaglig orientert med felles møtepunkter og felles målsetting for pasientene. Dette bidrar til en synliggjøring av samarbeidsformen og hvordan ulike faggrupper gir innspill til hverandre i felles møter. Studentene fikk speilet eget samarbeid gjennom avdelingens samarbeidsform, selv om studentene utforsket dette samarbeidet på sin måte. I en ordinær sengepost der samarbeidet mellom profesjonene forgikk som konsultasjoner med de andre, mer enn et tett samarbeid, kunne studentene som gruppe mer bli etterlatt til seg selv. Det kontekstuelle for studentene og det umiddelbare var å gå til eget arbeid som var faglig kjent. Å utforme samarbeidet i denne avdelingen var en utfordring for studentene. Både der tverrprofesjonelt samarbeid er etablert og der det ikke er etablert, ser vi at enkeltstudenter kan forsøke å kombinere arbeidet innenfor 
sin profesjon for så å utøve samarbeid etterpå. Praksisstedets kultur for samarbeid vil også prege studentenes mulighet til å samarbeide ut fra hvilke forventninger som ligger implisitt og eksplisitt. Når sykepleierstudenten først tok sine profesjonsspesifikke oppgaver i morgenstell, kunne det være fordi dette lå som en forventning, eller at studenten selv forventet dette som en oppgave som måtte gjøres. Dette kan ha vært en oppgave så naturlig for studenten at hun ikke reflekterte over at dette kunne være en læringsarena for andre studenter. Hugh Barr og Margo Brewer (2012) sier at det ikke bør være opp til studentene selv å utforme og finne muligheter for samarbeid. Utdanningsinstitusjonen og praksisstedet må sammen legge til rette og utforme mulighetene for studenter på samme praksissted, og veilederens rolle for å vise veien inn til samarbeidet blir viktig. I dette prosjektet var aksjonsforskningen rettet slik at studentene på slutten av sine respektive utdanninger skulle finne ut av sitt samarbeid. Å etablere samarbeidsrelasjoner tar tid, og med to uker til rådighet så kunne studentene utforme formen på samarbeidet og justere underveis. Samtidig er ikke denne tiden nok for å etablere et varig samarbeid. Sterke fagtradisjoner blir utfordret i TPS, der samarbeidet skjer over tid og ikke som enkeltstående oppgaver av gjøremål.

Hva sier studentene om å samarbeide? Studentene uttrykker samarbeid når de arbeider sammen hos samme pasient, eller når de sitter sammen og diskuterer. Der blir de enige om hva som skal gjøres, eller utfyller for hverandre hva de ser pasientens utfordringer er. De oppdager nye sider ved andre yrkesgrupper og ny faglig kunnskap om hverandre og om pasienten. En av studentene var også overrasket over hvor mye de hadde til felles. Den profesjonsspesifikke utdanningen holder fokus på eget område, og dermed blir andre profesjoners roller og samarbeidspartnere i praksis mer eller mindre usynlig.

Det er også helt nytt for studentene å arbeide sammen, og de ønsker å gjøre det uten konflikter. Når studentene opplever sprikende forventninger til hverandre, så forsøker de å samarbeide med dem som er tilgjengelige, eller de venter til den andre er på plass. TPS-praksis skal være noe mer enn samarbeid, det skal være en planlagt, målrettet aktivitet og samhandling som sikrer kvaliteten av tilbudet til pasientene (Barr et al., 2017). Studentene arbeidet aktivt med å etablere samarbeidet med medstudentene og finne en form som var hensiktsmessig for oppgavene rettet mot pasientene. 
Hensikten med å etablere tverrfaglige team er for å bedre helsetjenesten til pasienter med langvarige og kompliserte helseproblem (WHO, 2010). Studentene erfarte at de måtte bidra med egen kunnskap inn i samarbeidet og stå frem med sitt, men i samarbeid med andre. Studentene jobbet for første gang sammen med studenter fra andre profesjoner og var opptatt av å få til et samarbeid. Studentene oppdager at der de finner rom og form på samarbeidet, klarer de å lære av hverandre, de lærer også om hverandres kompetanse og fagområder, og de lærer sammen med hverandre i pasientarbeidet i en ny sosial praksis. Samtidig utfordrer denne typen praksis studentenes etablerte praksis gjennom sine år på eget studium. Der studentene har mange oppgaver de skal gjennomføre av sin ordinære praksis, så opplevdes det spesielt at de samlet brukte to uker på å samarbeide om få pasienter. Profesjonsutdanningene har til nå etterspurt profesjonsspesifikk kunnskap og i mindre grad hvordan studentene kan lære av å være del av et tverrfaglig team. Med ny Forskrift om felles rammeplan for helse og sosialfagutdanninger (2017) vil flere av de nye læringsutbyttene bli implementert, men det gjenstår å se når alle (de korte og de lange profesjonsutdanningene) får implementert disse, og med hvilken læringsarena nasjonalt.

\section{Avslutning - utfordringer med å etablere ny studentpraksis}

Å etablere en felles TPS-praksis, der studenter fra ulike profesjoner kommer sammen for å lære samarbeid og der de utfører egen profesjon i samarbeid med andre, krever grundig planlegging og samarbeid mellom praksissted og studieprogram over tid. Barr \& Brewer (2016, s. 747) sier også at en slik måte å organisere praksis på er å foretrekke når studentene har kommet et stykke ut $\mathrm{i}$ sin egen utdanning og har en viss profesjonsidentitet. Vi ser også i våre funn at studentene som er på slutten av sin utdanning, får utfordret sin forståelse av andres profesjonskunnskap og må orientere seg for å forstå hvilken rolle andre helseprofesjoner har i samarbeidet rundt pasientene. Det gjenstår å se om en slik praksis endrer måten de vil samarbeide med annet helsepersonell på når pasienter har langvarige og komplekse helseutfordringer, og hvordan de kan samarbeide om å bedre tilbudet for pasienten. Studentene i denne TPS-praksisen fikk i oppgave å organisere eget samarbeid og sitt eget arbeid 
i møte med pasientene. Dette krever en god og erfaren veileder som klarer å se alle studentene i samarbeid, ikke kun gjennom det profesjonsspesifikke, men som samarbeidende for bedre helsetjeneste for pasienten. Når studentene blir usikre i samarbeidet og ikke helt får tak i hverandre og går tilbake sitt eget, er det veilederne og avdelingen som kan utfordre dem til å se på nye måter å arbeide på. Veilederne diskuterte problematikken og bidro til at senere studentgrupper raskere fikk satt møtepunkter og fikk avklart forventningene til hverandre og til samarbeidet. Samarbeidet mellom studentene krever tid og planlegging, slik at de får prøvd ut og etter hvert etablere nye samarbeidsformer. Endring tar tid og det krever en felles innsats fra alle involverte. Studentene er vårt fremtidige helsepersonell, og vi må vi legge til rette for nye praksisformer. Gjennom studiet skal de få mulighet til reelt samarbeid, der de utfordrer tradisjonell profesjonsspesifikk praksis og læring. For å få gode tverrfaglige læringssituasjoner i praksis bør en ifølge Barr et al. (2017) tilrettelegge for interaktive, refleksive og personsentrerte oppgaver, som utfordrer roller og ansvar, etikk og praksisvaner, kunnskap og ferdigheter for å bygge gode og effektive samarbeidsformer, som videre utgjør en samarbeidende praksis. Studentenes refleksjoner gjennom intervjuene tyder på at de har fătt arbeidet med aspekter av dette i sin TPS-praksis, men vi vet enda for lite om dette følger dem videre i ny kunnskap for endring i sin yrkesutøvelse.

\section{Referanser}

Anderson, E. S., Ford, J., Kinnair D. J. (2016). Interprofessional Education and Practice Guide No. 6: Developing practice-based interprofessional learning using a short placement model. Journal of Interprofessional Care, 30(4), s. 433-440.

DOI: https://doi.org/10.3109/13561820.2016.1160040

Barr, H. \& Brewer, M. (2012) Interprofessional practice based education. I: J. Higgs,

R. Barnett, S. Billett, M. Hutchings \& F. Trede (red.). Practice-based education:

Perspectives and strategies. Rotterdam: Sense Publishers, s. 199-212.

Barr, H., Ford, J., Gray, R., Helme, M., Hutchings, M., Low, H., Machin, A.,

Reeves, S., (2017). Interprofessional Education Guidelines 2017. CAIPE, Fareham: UK.

Benner, P. (2010). Education nurses: a call for radical transformation». San

Francisco, Calif: Jossey-Bass 
Brewer, M. L. \& Stewart-Wynne, E. G. (2013). An Australian hospital-based student training ward delivering safe, client-centred care while developing students' interprofessional practice capabilities. Journal of Interprofessional Care 27, s. 482-488. DOI: https://doi.org/10.3109/13561820.2013.811639

Derbyshire, J. (2017). A case study exploring how the neurological practice context facilitates integrated learning for undergraduate health care students». Doctoral thesis. Northcumbria University.

Elliot, J. (1991). Action Research for Educational Change. Philadelphia: Open University Press.

Freeman, S., Wright, A. \& Lindqvist, S. (2010). Facilitator training for educators involved in interprofessional learning. Journal of Interprofessional Care 24, p. 375-385. DOI: https://doi.org/10.3109/13561820903373202

Frenk J, Chen, L., Bhutta, Z., Cohen, j., Crisp, N., Evans, T., Zurayk, H. (2010). Health professionals for a new century: transforming education to strengthen health systems in an interdependent world. Lancet, (376), s. 1923-1958. DOI: https://doi.org/10.1016/S0140-6736(10)61854-5

Graneheim, U. \& Lundman, B. (2004). Qualitative content analysis in nursing research: concepts, prosedures and measures to achieve trustworthiness. Nurse Education Today, 24, s. 105-112.

DOI: https://doi.org/10.1016/j.nedt.2003.10.001

Helse- og omsorgsdepartementet. Meld. St. 47 (2008-2009).

Samhandlingsreformen. Rett behandling - på rett sted - til rett tid. Hentet

3.11.21 https://www.regjeringen.no/no/dokumenter/stmeld-nr-47-2008-2009-/ id 567201

Hinselwood, R. D. \& Skogstad, W. (2000). Observing Organisations: Anxiety, Defence and Culture in Health Care. London og Philadelphia: Routledge. Jacobsen, F. B. (2016). An overview of pedagogy and organization in Clinical Interprofessional Training Units in Sweden and Denmark. Journal of Interprofessional Care, 30 (2), s. 156-164.

DOI: https://doi.org/10.3109/13561820.2015.1110690

Kemmis, S. \& McTaggart, R. (2000). Participatory action research. I N. K. Denzin and Lincoln (Eds.), Handbook of Qualitative Research (2. utg.). Solid Action on Globalization and Environment, CA: Thousand Oaks.

Kunnskapsdepartementet 2017. Forskrift om felles rammeplan for helse- og sosialfagutdanninger. https://lovdata.no/dokument/SF/ forskrift/2017-09-06-1353 Hentet 11.10.21 
Kvale, S. \& Brinkmann, S. (2010). Det kvalitative forskningsintervju. Oslo: Gyldendal Akademiske.

Lave, J. \& Wenger, E. (1991). Situated Learning: Legitimate Peripheral Participation. Cambridge: Cambridge University Press.

Malterud K. (2012). Systematic text condensation: a strategy for qualitative analysis. Scand J Public Health. 40(8), s. 795-805.

DOI: https://doi.org/10.1177/1403494812465030

McNiff, J. \& Whitehead, J. (2011). All You Need to Know about Action Research. Solid Action on Globalization and Environment (2. utg.). Thousand Oaks: Sage. Molander, A. \& Terum, L. I. (2008). Profesjonstudier. Oslo: Universitetsforlaget.

Norbye, B. (2016). Healthcare students as innovative partners in the development of future healthcare services: An action research approach. Nurse Education Today, (46), s. 4-9. DOI: https://doi.org/10.1016/j.nedt.2016.06.021

Reeves, S., Lewin, S., Espin, S., Zwarenstein M. (2010). Interprofessional Teamwork for Health and Social Care. Chichester, West Sussex: Blackwell Press.

Reeves, S., Palaganas, J., Zierler, B. (2017). An updated synthesis of review evidence of Interprofessional education. Journal of Allied Health, 46 (1), s. 56-61. https://pubmed.ncbi.nlm.nih.gov/28255597

Thistlethwaite J. (2012). Interprofessional education: a review of context, learning and the research agenda. Medical Education. 46 (1), s. 58-70. DOI: https://doi.org/10.1111/j.1365-2923.2011.04143.x

Thomas, L. \& Reeves, S. (2015). Sociological fidelity: keeping the patient at the heart of interprofessional learning. Journal of Interprofessional Care 29 (3), s. 77-178. DOI: https://doi.org/10.3109/13561820.2015.1035179

Wilhelmsson, M., Pelling, S., Ludvigsson, J., Hammar, M., Dahlgren, L.O., Faresjo, T. (2009). Twenty years experiences of interprofessional education in Linköping - Ground-breaking and sustainable. Journal of interprofessional care, 23, s. 12-33. DOI: https://doi.org/10.1080/13561820902728984

UiT Norges arktiske universitet. Strategiplan for Det helsevitenskapelige fakultet 2014-2020.

WHO (2010). Framework for action on interprofessional education and collaborative practice. http://apps.who.int/iris/bitstream/ handle/10665/70185/WHO_HRH_HPN_10.3_eng. pdf;jsessionid=03D86EF55CCB224E3248B69D85836634? sequence= 1 Hentet 11.10.2020 